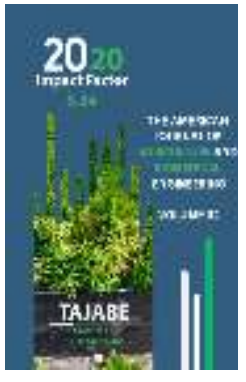

Journal Website: http://usajournalshub.c om/index,php/tajabe

Copyright: Original content from this work may be used under the terms of the creative commons attributes 4.0 licence.

\section{Effect Of Nitragine And Mineral Fertilizers On Soil Microbiological Properties In Planted As Secondary Legume Crops}

\author{
Abduvali Abdumannobovich Iminov \\ Dsc., Associate Professor, Tashkent State Agrarian University, Republic Of Uzbekistan \\ Salimjon Rakhimjon Ogli Hatamov \\ Ph.D., Senior Lecturer, Andijan Institute Of Agriculture And Agro-Technology, \\ Republic Of Uzbekistan \\ Sardor Shamsiddin Ogli Khayrullaev \\ Researcher, Tashkent State Agrarian University, Republic Of Uzbekistan
}

\title{
ABSTRACT
}

The article provides information on the effects of inoculation with nitragin and application of mineral fertilizers on the microbiological properties of the soil before sowing the seeds of legumes (soybeans, beans, mungbeans), grown as a secondary crop after winter wheat. At the end of the vegetation period of repeated crops, it was observed that the amount of microorganisms in the soil increased compared to the initial indicators, the amount of ammonifiers and oligonitrophils increased, and the amount of micromycetes and actinomycetes decreased. Before sowing the seeds of legumes (soybeans, mungbeans, beans) grown as a secondary crop, the amount of ammonifiers, oligonitrophils and micromycetes increased, and the amount of actinomycetes increased compared to the control option in the backgrounds treated with nitrogen-fixing bacteria.

\section{KEYWORDS}

Nitragin, nitrogen, phosphorus, potassium, microorganisms, ammonifiers, spores, oligonitrophylls, micromycetes, actinomycetes.

\section{INTRODUCTION}

Soil fertility and effective properties are closely related to the development and activity of soil microorganisms.
Microorganisms are actively involved in soil processes with high biochemical energy. They carry out the basic soil biological process, breaking down organic residues and forming 
new organic matter humus. It also creates the conditions for optimal growth and development of the crops grown by cleaning the environment using plant residues during the life cycle.

\section{THE DEGREE OF THE PROBLEM HAS BEEN} STUDIED

It was found that oligotrophies increase the amount of microorganisms, increase the concentration of carbon-containing organic compounds, and decrease the pedotrophils index and denitrifiers, microorganisms in nitrogen-containing compounds in shortrotation [6].

The use of nitragin in combination with mineral fertilizers, i.e., P90 K60 + nitragin and N30 P9o $\mathrm{K} 60+$ nitragin variants, resulted in the formation of the highest number of tuberous bacteria and an increase in yield of 3.3-5.4 C / ha. An increase in the amount of nitrogen led to a decrease in the production of tuberous bacteria or no production at all. It was observed that the yield increased only due to nitrogen fertilizer [3].

Once the bacteria enter the roots of legumes, they undergo a series of changes, initially in the form of like wands, then forming bacteroids, which absorb free nitrogen from the air and begin to accumulate in the roots of legumes [4].

\section{RESEARCH CONDITIONS AND METHODS}

Our research was conducted in 2015-2017 in the sierozem soils of Tashkent region. Before sowing soybean seeds as a secondary crop, nitragin in Bradyrhizobiumjaponicum SB5, mungbean seeds, Phaseolusradiatus148, and bean seeds Rhizobium phaseoli143 the following mineral fertilizer standards, PK 90:60, NPK 30:90:60, NPK 60:90:60 and NPK 90:90:60 kg / ha were tested.
The experiment included 24 options, each with an area of $240 \mathrm{m2}$, of which $120 \mathrm{~m} 2$ were taken into account. It was performed in three repetitions and the total area of the experiment was 1.73 ha.

Microbiological analyzes to determine the microbiological properties of soil were conducted at the Research Institute of Microbiology of the Academy of Sciences. Microbiological analyzes were performed on three replicates using the elective feed method based on a generally accepted methodology.

Indeed, when the agro-physical, water, waterphysical properties of the soil are normal, the movement of microorganisms in it becomes more active, resulting in increased soil fertility. Therefore, it is important to study the extent and scope of the impact of mineral fertilizer standards applied to the activity of microorganisms in the soil in cultivation as secondary legume crops grown as a repeat crop in short-crop rotation systems [1,5].

\section{RESEARCH RESULTS}

The soil micro-flora of the experimental field was determined from the main agronomic soil microorganisms - ammonifiers, spores, oligonitrophils, micromycetes, actinomycetes.

Ammonifiersconvert organic nitrogen in humus into a plant-derived form.

Oligonitrophils- carbon-hydrates in humus plant convert into plant-derived form.

Actinomycetes are among the most common microorganisms in the soil, eliminate plant diseases and assimilate organic and mineral forms of nitrogen [2].

According to the results of the initial microbiological analysis of the experimental field soils, in the $0-30 \mathrm{~cm}$ layer of soil from microorganisms aminifiers 5.2x107 g / koe, 
spores 4.6x106 g / koe, oligonitrophils 3.1×106 g / koe, micromycetes 5.5×104 g / koe, actinomycetes were observed to be $4.2 \times 105 \mathrm{~g} /$ koe.

At the end of the application period, it was observed that the amount of microorganisms in the soil increased compared to the initial indicators, the amount of ammonifiers and oligonitrophils increased, and the amount of micromycetes and actinomycetes decreased. With the increase in the amount of mineral fertilizers in the backgrounds treated with nitragin before sowing the seeds of legumes (soybeans, mungbeans, beans) grown as a secondary crop, the amount of ammonifier, oligonitrophil and micromycetes increased and the amount of actinomycetes decreased (1), (Table 1).

Table 1

\section{The amount of microorganisms in the soil of the experimental field, KOE / $\mathrm{g}$ in the soil (2016, at the end of the vegetation period).}

\begin{tabular}{|c|c|c|c|c|c|c|c|}
\hline $\begin{array}{l}\text { № } \\
\text { opt }\end{array}$ & $\begin{array}{c}\text { Norms of } \\
\text { mineral } \\
\text { fertilizers, } \mathrm{kg} / \\
\text { ha }\end{array}$ & $\begin{array}{l}\text { Soil } \\
\text { layer, } \\
\mathrm{cm}\end{array}$ & $\begin{array}{l}\text { Ammonium- } \\
\text { fixers }\end{array}$ & Spores & $\begin{array}{l}\text { Oligonitro- } \\
\text { phils }\end{array}$ & $\begin{array}{l}\text { Micromy- } \\
\text { cetes }\end{array}$ & $\begin{array}{l}\text { Actinomyc } \\
\text { etes }\end{array}$ \\
\hline \multicolumn{8}{|c|}{ Repeated crop, soybean } \\
\hline 1 & $\begin{array}{l}\text { Without } \\
\text { Fertilizers }\end{array}$ & $0-30$ & $7,5 \times 10^{6}$ & $1,5 \times 10^{5}$ & $4,5 \times 10^{5}$ & $3,5 \times 10^{4}$ & $7,5 \times 10^{4}$ \\
\hline 2 & $\mathrm{~N}_{30} \mathrm{P}_{90} \mathrm{~K}_{60}$ & $0-30$ & $7,5 \times 10^{6}$ & $2,2 \times 10^{5}$ & $5,2 \times 10^{5}$ & $4,5 \times 10^{4}$ & $1,5 \times 10^{5}$ \\
\hline 3 & $\mathrm{~N}_{60} \mathrm{P}_{90} \mathrm{~K}_{60}$ & $0-30$ & $7,5 \times 10^{7}$ & $3,0 \times 10^{6}$ & $3,7 \times 10^{6}$ & $6,5 \times 10^{4}$ & $2,2 \times 10^{5}$ \\
\hline 4 & $\mathrm{~N}_{90} \mathrm{P}_{90} \mathrm{~K}_{60}$ & $0-30$ & $6,0 \times 10^{7}$ & $4,2 \times 10^{6}$ & $9,7 \times 10^{5}$ & $5,7 \times 10^{4}$ & $2,5 \times 10^{5}$ \\
\hline 5 & $\begin{array}{c}\text { Nitragin } \\
\text { (without } \\
\text { fertilizers) } \\
\end{array}$ & $0-30$ & $7,5 \times 10^{7}$ & $4,5 \times 10^{6}$ & $2,7 \times 10^{6}$ & $6,7 \times 10^{4}$ & $3,5 \times 10^{5}$ \\
\hline 6 & $\mathrm{P}_{90} \mathrm{~K}_{60}+$ Nitragin & $0-30$ & $7,5 \times 10^{7}$ & $4,6 \times 10^{6}$ & $3,5 \times 10^{6}$ & $7,5 \times 10^{4}$ & $4,5 \times 10^{5}$ \\
\hline 7 & $\begin{array}{c}\mathrm{N}_{30} \\
\mathrm{P}_{90} \mathrm{~K}_{60}+\text { Nitragin }\end{array}$ & $0-30$ & $7,5 \times 10^{8}$ & $4,7 \times 10^{6}$ & $4,5 \times 10^{6}$ & $8,5 \times 10^{4}$ & $6,5 \times 10^{5}$ \\
\hline 8 & $\begin{array}{c}\mathrm{N}_{60} \\
\mathrm{P}_{90} \mathrm{~K}_{60}+\text { Nitragin } \\
\end{array}$ & $0-30$ & $9,0 \times 10^{7}$ & $4,5 \times 10^{6}$ & $3,7 \times 10^{6}$ & $7,5 \times 10^{4}$ & $5,5 \times 10^{5}$ \\
\hline \multicolumn{8}{|c|}{ Repeated crop, mungbean } \\
\hline 9 & $\begin{array}{l}\text { Without } \\
\text { Fertilizers }\end{array}$ & $0-30$ & $3,0 \times 10^{6}$ & $1,5 \times 10^{6}$ & $9,0 \times 10^{5}$ & $4,5 \times 10^{4}$ & $3,5 \times 10^{4}$ \\
\hline 10 & $\mathrm{~N}_{30} \mathrm{P}_{90} \mathrm{~K}_{60}$ & $0-30$ & $7,5 \times 10^{7}$ & $2,2 \times 10^{6}$ & $1,9 \times 10^{6}$ & $4,5 \times 10^{4}$ & $4,2 \times 10^{4}$ \\
\hline 11 & $\mathrm{~N}_{60} \mathrm{P}_{90} \mathrm{~K}_{60}$ & $0-30$ & $3,7 \times 10^{8}$ & $6,0 \times 10^{6}$ & $3,9 \times 10^{6}$ & $6,5 \times 10^{4}$ & $4,5 \times 10^{4}$ \\
\hline 12 & $\mathrm{~N}_{90} \mathrm{P}_{90} \mathrm{~K}_{60}$ & $0-30$ & $7,5 \times 10^{7}$ & $3,7 \times 10^{6}$ & $2,6 \times 10^{6}$ & $7,2 \times 10^{4}$ & $1,5 \times 10^{5}$ \\
\hline 13 & $\begin{array}{c}\text { Nitragin } \\
\text { (without } \\
\text { fertilizers) } \\
\end{array}$ & $0-30$ & $4,5 \times 10^{7}$ & $4,0 \times 10^{6}$ & $3,2 \times 10^{6}$ & $7,2 \times 10^{4}$ & $2,5 \times 10^{5}$ \\
\hline 14 & $\mathrm{P}_{90} \mathrm{~K}_{60}+$ Nitragin & $0-30$ & $2,3 \times 10^{8}$ & $4,2 \times 10^{6}$ & $3,9 \times 10^{6}$ & $7,2 \times 10^{4}$ & $4,2 \times 10^{5}$ \\
\hline 15 & $\begin{array}{c}\mathrm{N}_{30} \\
\mathrm{P}_{90} \mathrm{~K}_{60}+\text { Nitragin }\end{array}$ & $0-30$ & $5,2 \times 10^{8}$ & $4,7 \times 10^{6}$ & $3,7 \times 10^{6}$ & $7,5 \times 10^{4}$ & $4,7 \times 10^{5}$ \\
\hline 16 & $\begin{array}{c}\mathrm{N}_{60} \\
\mathrm{P}_{90} \mathrm{~K}_{60}+\text { Nitragin } \\
\end{array}$ & $0-30$ & $7,5 \times 10^{7}$ & $3,0 \times 10^{6}$ & $6,2 \times 10^{6}$ & $7,3 \times 10^{4}$ & $4,5 \times 10^{5}$ \\
\hline \multicolumn{8}{|c|}{ 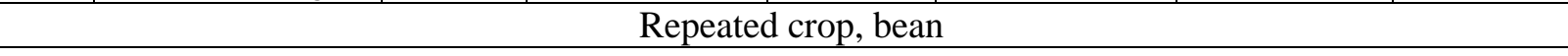 } \\
\hline
\end{tabular}


The American Journal of Agriculture And Boimedical Engineering (ISSN - 2689-1018)

Published: August 30, 2020 | Pages: 169-172

Doi: https://doi.org/10.37547/tajabe/Volumeo2Issue08-22

2020: $5 \cdot 34$

\begin{tabular}{|c|c|c|c|c|c|c|c|}
\hline 17 & $\begin{array}{c}\text { Without } \\
\text { Fertilizers }\end{array}$ & $0-30$ & $4,2 \times 10^{7}$ & $3,5 \times 10^{6}$ & $8,2 \times 10^{5}$ & $2,2 \times 10^{4}$ & $3,5 \times 10^{5}$ \\
\hline 18 & $\mathrm{~N}_{30} \mathrm{P}_{90} \mathrm{~K}_{60}$ & $0-30$ & $4,5 \times 10^{7}$ & $4,0 \times 10^{6}$ & $1,1 \times 10^{6}$ & $3,2 \times 10^{4}$ & $4,2 \times 10^{5}$ \\
\hline 19 & $\mathrm{~N}_{60} \mathrm{P}_{90} \mathrm{~K}_{60}$ & $0-30$ & $6,7 \times 10^{7}$ & $4,7 \times 10^{6}$ & $4,1 \times 10^{6}$ & $7,5 \times 10^{4}$ & $4,5 \times 10^{5}$ \\
\hline 20 & $\mathrm{~N}_{90} \mathrm{P}_{90} \mathrm{~K}_{60}$ & $0-30$ & $7,5 \times 10^{7}$ & $4,5 \times 10^{6}$ & $2,9 \times 10^{6}$ & $5,5 \times 10^{4}$ & $4,3 \times 10^{5}$ \\
\hline 21 & $\begin{array}{c}\text { Nitragin } \\
\text { (without } \\
\text { fertilizers) }\end{array}$ & $0-30$ & $3,0 \times 10^{8}$ & $3,5 \times 10^{6}$ & $4,7 \times 10^{6}$ & $6,5 \times 10^{4}$ & $4,5 \times 10^{5}$ \\
\hline 22 & $\mathrm{P}_{90} \mathrm{~K}_{60}+$ Nitragin & $0-30$ & $6,7 \times 10^{8}$ & $4,2 \times 10^{6}$ & $5,2 \times 10^{6}$ & $7,5 \times 10^{4}$ & $5,5 \times 10^{5}$ \\
\hline 23 & $\begin{array}{c}\mathrm{N}_{30} \\
\mathrm{P}_{90} \mathrm{~K}_{60}+\text { Nitragin }\end{array}$ & $0-30$ & $9,0 \times 10^{8}$ & $4,8 \times 10^{6}$ & $7,5 \times 10^{6}$ & $8,5 \times 10^{4}$ & $5,7 \times 10^{5}$. \\
\hline 24 & $\begin{array}{c}\mathrm{N}_{60} \\
\mathrm{P}_{90} \mathrm{~K}_{60}+\text { Nitragin }\end{array}$ & $0-30$ & $7,5 \times 10^{8}$ & $4,5 \times 10^{6}$ & $6,8 \times 10^{6}$ & $7,5 \times 10^{4}$ & $5,5 \times 10^{5}$ \\
\hline
\end{tabular}

According to the results of the study, in variants 1, 9, 17 (control) ammonifiers 7.5 ×106, which did not use nitragin and no mineral

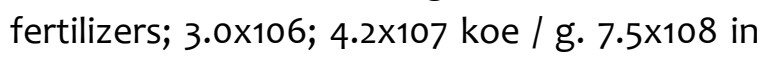
variants $7,15,23$, where the norm of mineral fertilizers NPK 30:90:60 kg / ha was applied on backgrounds treated with nitragin before sowing soybean, mungbean and bean seeds; 5.2x108; 9.0x108 koe / g. formed. The above results were also observed in the number of oligonitrophils.

\section{CONCLUSION}

Application of mineral fertilizers NPK 30:90:60 $\mathrm{kg} \mathrm{/} \mathrm{ha} \mathrm{when} \mathrm{sowing} \mathrm{seeds} \mathrm{of} \mathrm{legumes}$ (soybeans, mungbeans, beans) as a repeat crop after autumn cereal crops in shortrotation crop rotation systems with NPK 30:90:60 kg / ha, ammonifiers, oligonitrophils and causes an increase in the amount of micromycetes.

\section{REFERENCES}

1. Vinogradskiy S.N. Microbiology of soil. Problems and methods. Moscow: izd. AN USSR, 1952. - $410 \mathrm{p}$.

2. Iminov A.A. Dissertation for the degree of Doctor of Agricultural Sciences on
"Improvement of agrotechnologies for high and quality yields of primary and secondary crops in short-crop rotation systems." Tashkent, 2020. - 200 p.

3. Islamova $Z$. The effect of nitragin and mineral fertilizers on soybean yield. Agro science, № 3 [19], 2011. - p. 15.

4. Mishustin E.N., Shilnikova V.K. Biological fixation of atmospheric nitrogen. Moscow: Kolos. 1968. - p. 395.

5. Ratner E.I. Nutrition of plants and application of fertilizers. Moscow: Science, 1965. - $320 \mathrm{p}$.

6. Khaliqov B.M. New crop rotation systems and soil fertility. Tashkent, 2010. -118 p. 